\title{
Economic Hardship and Social Capital in Europe. A Comparative Analysis of 27 Democracies*
}

Pirmin Bundit

Accepted for Publication in the European Journal of Political Research

\begin{abstract}
This paper evaluates whether economic hardship affects social capital in Europe. Comparing 27 European countries we evaluate the impact of personal experiences of economic hardship in Europe on civic life, namely associational voluntary activity. Our empirical analyses of the Eurobarometer data indicate that individual economic hardship has indeed a negative effect on voluntary engagement in Europe. However, our result is qualified in two respects. First, we find that the effect of individual economic hardship is contingent upon education. Second, we show that this effect only refers to volunteering for associations providing solidarity goods (Putnam-Groups). These results have broader implications for understanding how economic hardship shapes the social capital within society.
\end{abstract}

Keywords: Economic Hardship, Social Capital, Social Participation, Volunteering, Europe

\footnotetext{
* Previous versions of this article were presented at the SPSA Annual Conference, Geneva, 5-6 February 2018, the IPW Kolloquium, Bern, 4 May 2018 and the EPSA Annual Conference, Vienna, 21-23 June 2018. We thank all the participants for their feedback, particularly Julian Limberg and Tina Freyburg. Moreover, we would like to thank Marc Bühlmann, Maximilian Filsinger, Simon Lanz, Annabelle Littoz-Monnet, Hugo Marcos-Marne, Michael A. Strebel, Raphael Reinke and Adrian Vatter for their valuable remarks. Special thanks go to Nathalie Hofstetter for her excellent research assistance. We are grateful to Isabelle Engeli, Emiliano Grossman and Sofia Vasilopoulou as well as the two anonymous reviewers for their valuable comments.

† Swiss Graduate School of Public Administration (IDHEAP), University of Lausanne, Switzerland.

\$2Institute of Political Science, University of Bern, Switzerland.
} 
Economic hard times lower our incomes, raise our debt levels, and make our jobs more precarious. Stress rises, and civic engagement falls. The case seems open and shut. However, the defense has some strong counterevidence. [...] The economy went up and down and up and down, but social capital only went down (Putnam, 2000, 193).

\section{Introduction}

To date, only little attention has been paid to relationship between economic hardship and social capital in Europe. ${ }^{1}$ This is quite startling, since economic downturns might have major implications for the societal life. In general, an economic deprivation can be an opportunity and a risk at the same time for the social participation of citizens. While some studies suggest that citizens have strong incentives to engage in politics and society (Jones, 2006; Musick \& Wilson, 2007), others argue that economic hardship will have a negative effect on the availability of resources that are required for civic engagement (Brady et al., 1995; Putnam, 2000). In this vein, news articles published in the time of the financial crises have reported that social capital seems to be flourishing during economic downturns, observations of social capital in Iceland, Greece, Spain and Portugal after the crisis in 2008 indicate that social activity was intensified and ties with friends were strengthened (Arampatzi, 2017; Growiec et al., 2012; Lim \& Laurence, 2015; Sotiropoulos, 2014; Wosiek, 2016; Zambeta \& Kolofousi, 2014). ${ }^{2}$ However, experiences of Indonesia during the so-called Asian crisis between 1997 and 1998 suggest that civic engagement of people decreases in economic hard times (Frankenberg et al., 1999, 39). Furthermore, ethnographic research of the Great Depression era presents rather pessimistic lessons on the impact of economic hardship on aspects of the social fabric, too (Lim \& Laurence, 2015; Lim \& Sander, 2013). Evaluating the civic life of an industrial village in Austria Jahoda et al. (2002) experienced that joblessness in Marienthal in the 1930s lessened the attendance of clubs, voluntary organizations, and weakened social relations in

\footnotetext{
1 A notable exception are Andrews et al. $(2014,565)$ who focus on "social cohesion as an attitudinal phenomenon reflecting individuals' perceptions of the quality of the relationships between different social groups. While these authors as well as Blekesaune (2013) use the term "economic strain" instead of economic hardship, we refer to the latter in order to consistently present our key concepts.

${ }^{2}$ For example, the Guardian reported that "the voluntary sector may be the one industry benefiting from the economic downturn" (The Guardian, 21.12.2008). According to The Telegraph (21.4.2009), "thanks to the recession...we're rediscovering the joys of old-fashioned neighbourliness". Finally, The Washington Post (4.5.2009) thinks "there has been an uptick of "neighboring" in the recession".
} 
general. In addition, Bakke's (1933) analysis of the Economic Depression in London reveals that unemployed men reduced their social activities. Moreover, while Lim \& Laurence (2015) argue that a decline of volunteering in the United Kingdom is more related to community-level factors such as civic organizational infrastructure and cultural norms of trust and engagement than to personal experiences of economic hardship, according to Lim \& Sander (2013) being unemployed is associated with lower levels of civic life in the United States. To summarize, a review of the literature yields ambiguous conclusions. Moreover, hitherto, the relationship between economic hardship and social capital has mainly been the subject of single country studies. To the best of our knowledge, there has been no study that systematically examines the impacts of economic hardship on civic engagement in a strictly comparative manner.

Against this background, comparing 27 European countries we evaluate the impact of personal experiences of economic hardship on civic life. In particular, we focus on whether people are more or less likely to volunteer their time and energy to help others in they experience economic hard times, thus scrutinizing one important aspect of social capital, namely associational voluntary activity. According to Putnam (2000, 116-117) “...volunteering...- our readiness to help others - is by some interpretations a central measure of social capital (...). Thus, any assessment of trends in social capital must include an examination of trends in volunteering". In this respect, volunteering is a cornerstone of civil society and therefore a negative effect of economic hardship would undermine the social glue that holds politics and society together.

In spite of the contrary opinions in the literature, the perspective of negative social impacts of recessions appears most persistent and dominant. Therefore, we concentrate on this hypothesis and not on its opposite. Accordingly, since some people are more vulnerable towards economic downturns than others (Singer, 2011), we argue that the individual economic hardship has a negative effect on volunteering. Individual economic hardship decreases the likelihood to volunteer due to limited time and money resources. Albeit economic capital influences the ability for voluntary activity within clubs and organizations, however, citizens with a high human capital can substitute financial 
shortcomings. Moreover, this study maintains that the social effects of economic hardship differ across the groups of voluntary associations. In economic hard times, individuals will focus on non-solidarity (so called "Olson"-) associations, which provide an economic benefit for their members.

In this article, we focus on the EU-27, where many citizens experienced economic hardship in the context of the European economic crisis. This case is particularly suitable for examining the arguments developed in the previous section. The member states of the European Union do not only provide a large economic heterogeneity, but also offer different political systems and cultural traditions. More specifically, our arguments are analyzed empirically by using data from Eurobarometer 75.2. that was conducted in the peak of the economic crisis in 2011 (European Commission, 2014). Against a "background of financial, economic and social crisis affecting all sections of European society", this Eurobarometer focuses exclusively on volunteer work (European Parliament, 2011, 2). Here, in addition to questions about volunteering, individual consequences of economic hardship are also examined in 27 European countries. In this regard, providing the first cross-national comparative study of economic hardship and social capital, we not only complement previous single country analysis and put them in a broader perspective but are also able reconcile some of the contradicting findings so far.

Our contribution is relevant in order to understand how economic hardship affects social capital. By putting civic engagement at the center of our analysis, we propose a theoretical framework for the consequences of the economic hardship on the individual level. While existing work focuses on political participation, our study broadens the scope and shows that economic hardship also has important consequences for the social fabric. The empirical analyses of 27 European countries suggest that the effects of economic hardship on volunteering might be largely negative. There is, however, also a message of hope. According to our analyses, societies are able to compensate this negative effect by increasing their investments in human capital. The layout of the paper is as follows. Section 2 introduces the concept of social capital and discusses 
the impact of economic hardship on volunteering as a cornerstone of social capital. Next, section 3 describes our data and methods and section 4 presents our empirical results. A discussion of the major findings concludes the paper.

\section{Theoretical Background: Social Capital in Economic Hard Times}

Social capital has become increasingly popular in a wide range of social science disciplines since the 1990s (Bjørnskov \& Sønderskov, 2013; Engbers et al., 2017; Freitag, 2003, 2006; Knack, 2002; Koos, 2011; Lin, 2002; Putnam, 2001; Williams, 2011). The idea behind the concept of social capital is extremely simple: Social capital is derived from resources embedded in social relations (Coleman, 1988; Lin, 2002; Portes, 1998). In doing so, scholars condense social networks and the associated norms of reciprocity and social trust as social capital, since social networks create an individual or collective value (Putnam \& Goss, 2002, 8).

In general, literature distinguishes between two forms to network-based social capital. On the one hand, social capital builds up in a variety of informal social networks. On the other hand, social capital can be organized formally, such as in voluntary associations, which "once brought into existence for one set of purposes, can also aid others, thus constituting social capital available for use" (Coleman, 1988, 108). Although formal organizational affiliation is only one dimension of community networking, and not necessarily the most important, there are three reasons why volunteering organizations capture the extent of social capital. ${ }^{3}$ First, the organizational setting within voluntary associations ensures that individuals interact on a regular basis. In doing so, repeated social interactions can solve free rider problems and reduce opportunism (Glaeser et al., 2002). Second, the existence of a voluntary organization implies that its members are willing to subordinate immediate pay-offs to long-term goals (Putnam, 1995, 72). Handy \& Greenspan (2009) show that volunteers are more likely to be long-

\footnotetext{
${ }^{3}$ Some authors question the major role of voluntary organizations and put more importance to school, family, neighborhood, or workplace, since most people devote more time to these institutions than to associational engagement (Levi, 1996; Newton, 1999). In addition, Foa \& Ekiert (2017) argue that post-communist societies are rather organized through transnational civic networks than through voluntary organizations.
} 
term members of a congregation and hence to commit themselves to social enhancement. Finally, and most importantly, an organization can sanction noncooperation by the members using various formal and informal mechanisms (Van Deth et al., 2002, 39). Since associations provide various advantages for their members, citizens have certain incentives to join them. Associations are social capital for those who have access to them by establishing obligations, expectations and trustworthiness, creating channels for information, and setting norms backed by efficient sanctions (Coleman, 1988, 103-104). People join organizations in response to tangible or intangible incentives, and social capital is created by their ensuing membership. Furthermore, associations may help citizens to bridge contacts and teach them to accept other individuals or cultures, for they function as a gathering place for all kind of social types and backgrounds. As a consequence, they reinforce the "habits of the heart" (Putnam, 1993a, 11). Since most forms of associational attachment help to create reciprocity and cooperation, associations provide the social foundations for a vibrant democracy (Curtis et al., 1992, 2001; Norris, 2001; Putnam, 1995; 2001).

In this vein, following Tocqueville's view that the lifeblood of a democracy depends on the robustness of its associational activity, voluntary associations are a society's major "schools for democracy", fostering democratic attitudes and civic skills. Compared to non-members, for example, members of associations are more politically active and politically informed. Moreover, within voluntary organizations citizens learn the skills of democratic discussion and organization which lead them to support democratic norms in general (Freitag, 2006). Moreover, voluntary associations are considered to forge the cross-cutting ties and social networks that bind a society together, and to link citizens to the political system and its institutions (Paxton 2002). Additionally, organizations aggregate and articulate interests, provide resistance to the political center, and frame the range and variety of competing and cooperating groups which constitute a pluralistic society (Andrews, 2012; Freitag, 2006, Putnam 1993 Rothstein \& Stolle 2003).

Although associational volunteering is a cornerstone of the social capital of a society (Engbers et al., 2017; Putnam, 2001), this kind of engagement differs highly across 
countries. ${ }^{4}$ According to Wilson $(2012,192-193)$, there has been a number of theories that try to explain cross-national differences in associational volunteering. First democratization theory makes the assumption that democratic values enhance volunteering. In this regard, authors argue that the low civic engagement by the former Soviet countries can be explained by the low level of democratization (Voicu \& Voicu, 2009). Second, welfare state theory argues that public spending will crowd out private investments of money or time (Carpenter \& Myers, 2010, 912). Finally, social origins theory assumes that regime differences lead to variation in volunteer rates, ranging from a "liberal" to a "traditional" model. While the liberal model is based on private initiatives and nonprofit organizations, the traditional model is influenced by premodern forms of helping and a small nonprofit sector (Kang et al., 2011). However, those theories have been harshly criticized. While more recent studies show that civil societies of former soviet countries are rather organized through transnational communities than through voluntary associational (Foa \& Ekiert, 2017), scholars argue that welfare expenditures actually stimulates volunteerism, since poorer people obtain resources for their civic engagement (Hank, 2011; Stadelmann-Steffen, 2011). While social scientists have long studied various forms of volunteering behavior, few have directly examined how economic hardship affect volunteering activities or civic engagement in general.

However, referring to modernization theory, one might argue that that social behavior, e.g. associational life is dependent on collective resources (Lipset, 1960; Schofer \& Fourcade-Gourinchas, 2001). Moreover, social capital is linked with enhanced education, more leisure time, and other individual-level characteristics that may increase voluntary engagement in associations. The other way round, Putnam (2000,192-193) argues that economic downturns might heavily inhibit civic engagement. People who feel financially strapped are much less engaged in the community life than those who are better off. In particular, the great depression paused the rising tide of civic

\footnotetext{
${ }^{4}$ A common distinction is made between formal and informal volunteering (Wilson, 2000, 2012). Formal volunteer work is carried out within an organizational context such as a club or association. Informal volunteering refers to activities such as helping and supporting friends, neighbors, acquaintances and relatives (outside of one's own household) that take place directly between the people involved and outside of any formally organized structure. We focus our study on formal volunteering. We argue that formal volunteering is characterized by a commitment of time and energy as well as a regularity and expectedness of social exchange.
} 
engagement during the last century. In general, previous literature indicates that the economic context influence civic engagement by limiting individual resources. The voluntarism model argues that citizens will less likely engage due to limited resources (Brady et al., 1995; Verba et al., 1995). According to this view, citizens who possess personal resources such as time, money, and civic skills are more likely to engage (Berinsky, 2002). In doing so, the model argues that access to money should be associated with a higher level of volunteering (McBride et al., 2011; Musick \& Wilson, 2007; Pho, 2008; Tang et al., 2010). As consequence, economic downturns should lead to a decrease in volunteering, since resources are decreasing in economic hard times (Kern et al., 2015, 470). Muñoz et al. (2014) show that citizens rather focus on their own situation than spending their shrinking resources on civic engagement. In this respect, people may be less likely to volunteer in hard times because they feel less safeguarded financially and thus work harder to protect their jobs and survive the recession (Lim \& Laurence, 2015, 322). In addition, although formal volunteers are also likely to be rooted in organizational networks that stimulate their participation, resources for those organizations may dry up in hard times, making it difficult for them to sustain mobilizing efforts (Lim \& Laurence, 2015, 323). Moreover, unlike informal helping behaviors, formal volunteering is less spontaneous and characterized by less flexibility and a strong commitment to regularly engage. It can be assumed, however, that in times of economic hardship flexibility is particularly sought in order to master everyday life worries. Hence, we argue that individuals who face financial difficulties will less likely volunteer in associations than individuals who do not have financials troubles due to the European crises:

\section{Hypothesis 1: Economic hardship is negatively related to formal volunteering.}

However, one might assume that economic hardship does not affect the entire population in the same way. Voluntary engagement often requires certain knowledge and skills, which are rather provided from citizens with a high socio-economic status. Moreover, they are also more likely to be asked to volunteer (Wilson \& Musick, 1997). In particular, education seems to play an important role for volunteering, since it increases the awareness towards social problems and the importance of civic 
engagement. In general, education has a positive effect on self-expression values, which goes together with trust in people and peaceful collective action (Welzel, 2010; Welzel \& Inglehart, 2010). In doing so, education enhances the motivation in order to engage voluntarily following value-oriented reasons (Musick \& Wilson, 2007, 75; Wilson, 2000; 2012). Indeed, several studies show that education is usually a powerful predictor for volunteering (Gesthuizen et al., 2008; Kim et al., 2007; Shye, 2010; Wilson, 2012). In the following, we argue that education not only has a direct effect on civic engagement, but also that it attenuates the effects of economic hardship. Albeit citizens might be experience financial difficulties, they still want to engage voluntarily. Citizens might be motivated by altruistic motivations such as reciprocity, which evokes obligations towards others on the basis of their past behavior rather than on the basis of expectations of future rewards (Manatschal \& Freitag, 2014). In doing so, highly educated citizens are more aware of such social norms, in particular in economic hard times. Thus, we suggest that education moderates the effect of economic hardship:

Hypothesis 2: Economic hardship is negatively related to formal volunteering, but weaker for citizens with a high education.

In addition, previous research on volunteering shows that the different groups of associations vary strongly in the reason for their existence (Mahoney \& Beckstrand, 2011; Rotolo, 1999; Stolle \& Rochon, 1998). Knack \& Keefer (1997, 1273), for example, argue that groups that engage in associational activities can be distinguished between "Olsonian" and "Putnam-esque" groups, since associations might have diverse purposes that attract different sorts of human beings. While Putnam (1993a, 8990) argues that associations instill in their members habits of cooperation, solidarity and public-spiritedness, Olson (1965) emphasizes the tendency of associations to pursue private interests and lobbing for individual preference. On the one hand, Putnam-Groups pursue inclusive goods, which can be characterized as social, nonexcludable, and unlimited. For instance, religious associations, charitable organizations, and sport clubs belong to this category. On the other hand, Olson-Groups secure advantages for their members and pursue individual material goods, which are individual, scarce, and excludable. Interest groups, unions, civil service, and political 
groups are usually assigned to this category (Warren, 2001; Zmerli, 2003). With these terms, we argue that citizens will focus on the most important needs in times of recession, since resources become scarce in such periods. Putnam-Groups providing solidarity goods will be less attractive for volunteering if individuals experience economic hardships. In contrast, selfish and strategic motivations are expected to relate to volunteering in Olson-Groups devoted to non-solidarity goods. Hence, OlsonGroups that serve a professional purpose might be more attractive during financial downturns to weather the time of economic hardship. Thus, we assume that individuals have stronger incentives to engage in Olson-Groups from which they expect an economic benefit. In this regard, we argue that the effect of economic hardship will be weaker for Olson-Groups than for Putnam-Groups.

Hypothesis 3: Economic hardship is negatively related to formal volunteering, but only for solidarity Putnam-Groups and not for non-solidarity Olson-Groups.

To sum up, we expect that economic hardships at the individual level has a negative effect on volunteering due to limited resources. However, we argue that other human capital resources moderate this effect. Furthermore, we expect different results across the Putnam- und Olson-Groups. We will test these assumptions in the context of the economic crisis in Europe, which has been prevalent since 2008.

\section{Research Design}

In the remainder of the article the relationships presented above will be empirically tested. We use different sources of data in order to test our hypotheses. Referring to voluntary activity and other individual data, we use the Eurobarometer which was shortly conducted after the peak of the financial crisis in Europe (European Commission, 2014). The Eurobarometer project is a comparative large-N survey conducted twice a year since 1973. Respondents are selected following a multi-stage, random probability sampling procedure from the total population aged 15 and above. Interviews are then conducted face to face at the respondent's home. To ensure crosscountry comparability of survey items, questionnaires are carefully designed, translated and back-checked. For our study, we use Eurobarometer 75.2 on volunteering in an era of 
economic crises in the EU member countries. The survey work was fielded between April and May 2011. Its sample population is representative at the national level with a total of 26,825 respondents. In addition, we use structural indicators on the country level, which is provided by the Comparative Political Data Set (Armingeon et al., 2014). Our dataset includes information for the EU-27: Austria, Belgium, Bulgaria, Cyprus, Czech Republic, Germany, Denmark, Estonia, Spain, Finland, France, United Kingdom, Greece, Hungary, Ireland, Italy, Lithuania, Luxembourg, Latvia, Malta, Netherlands, Poland, Portugal, Romania, Sweden, Slovenia, and Slovakia. ${ }^{5}$

Our dependent variable is the reported involvement in a voluntary association. In the Eurobarometer survey, the respondents were asked if they "currently have a voluntary activity on a regular or occasional basis". In doing so, they could either respond with "no", "on an occasional basis", or "on a regular basis". Hence, our dependent variable is ordered and comprises three different categories. Regarding the group of associations, we distinguish between solidarity Putnam-Groups (sport, community, charity) and non- solidarity Olson-Groups (union, professional, political). About 25 percent of the respondents indicate that they are volunteers, which is in line with previous findings (Plagnol \& Huppert, 2010; Ruiter \& De Graaf, 2006).

In order to measure our main independent variable, we focus on the personal experiences of economic hardship. Reference group theory indicates that people regularly assess their economic situation by comparing their standing with that of relevant others (Andrews et al. 2014, 567). In this vein, respondents to Eurobarometer 75.2 were asked whether they have problems to pay their bills: "During the last twelve months, would you say you had difficulties to pay your bills at the end of the month...?". In doing so, the respondents had the possibility to tell the interviewers whether this would be most of time, from time to time or almost never. We have combined the former two answers in order to make the variable dichotomous (0: no economic hardship; 1: economic hardship). Measures of this type have been applied in several prior studies of economic

\footnotetext{
${ }^{5}$ For historical reasons there is a sample for West and East Germany. The United Kingdom is represented by a sample for Great Britain and Northern Ireland, so we have a total of 29 units in our dataset.
} 
hardship (Andrews et al. 2014; Blekesaune 2013). In addition, the respondents' education is measured by the age when they stopped full-time education. ${ }^{6}$

We introduce a range of potential control variables both at the micro as well on the macro that may influence the relationships we study. On the individual level, we control for sex since previous studies have shown that men are more likely to volunteer than women as well as they volunteer for different kind of activities (Eagly, 2009). Second, several studies show that individuals volunteer more often in the mid-and later life, since they have settled roles such as steady jobs, marriage and parenting (Flanagan \& Levine, 2010). For the same reason, we also integrated the household size in our models. Forth, volunteering is generally more common in rural than in urban areas (Petrzelka \& Mannon, 2006). Fifth, we control whether the respondents are married and the size of the household. Sixth, we include a variable for the occupation status of the respondent, since upper classes have a higher level of cognitive competences as well as a larger social network (Wilson \& Musick, 1998; Taniguchi 2012). On the country-level, we include as control variables we include the change in the growth rate of real GDP per capita for the time of the crisis (2008-2011). In addition, we also include the change in the unemployment rate (\% of total labor force) as well as the difference of total social expenditure (\% of GDP) for the same period of time (Kern et al. 2015). We also added a dummy for East European countries, since their voluntarism rates are usually smaller (Foa \& Ekiert, 2017).

The observations in our data set are not independent from one another, but nested in countries. Moreover, our data set is hierarchically structured, which is why we rely on a multi-level model. According to Steenbergen \& Jones (2002, 219-220), ignoring the clustering of the data structure could lead to biased standard errors that would overestimate the significance of effects. In addition to account for correct standard errors, multi-level models also allow us to determine the direct effects of the countrylevel variables. Hence, we fit multilevel mixed-effects ordered logistic regressions since all outcomes are ordered variables.

\footnotetext{
${ }^{6}$ Table A1 in the appendix provides an overview on the operationalization of the variables.
} 


\section{Empirical Results}

As a first step, we look at the distribution of volunteers and citizens with economic hardship across Europe. Figure 1 shows that both values highly vary across the European countries. On the one hand, we observe a regional difference regarding voluntary work. In the Netherlands, almost 60 percent of the respondents volunteer at least on an occasional basis. The Scandinavian countries Denmark and Finland also belong to the countries with the highest share of volunteers, as well as the Germanspeaking countries Austria, Luxembourg, and Germany. In contrast, the countries from East and Southern Europe are ranked amongst the countries with the lowest volunteering rates. In Poland, only about 10 percent engage in a voluntary association. In sum, the analyses of the Eurobarometer data confirm previous studies, which show that the level of voluntary engagement is usually higher amongst West European countries (Foa \& Ekiert, 2017; Huppert et al., 2009; Ruiter \& De Graaf, 2006; Schofer \& Fourcade-Gourinchas, 2001).

-Figure 1 around here-

On the other hand, the figures show that the nation with a lower percentage of volunteers are amongst those countries whose citizens often experience economic hardship. In Greece and Bulgaria, almost 80 percent of the respondents reported that they have problems to pay their bills by the end of the month. Portugal, Lithuania, and Cyprus also belong to the countries with the lowest shares of voluntary engagement and in these countries reported more than 60 percent economic hardship. Only Ireland and Italy deviate from this general picture by having a large percentage of volunteers despite many citizens reported economic hardship. Both countries were in particular strong affected by the economic crisis but also have a strong tradition of civic society (Fukuyama, 2001; Powell \& Guerin, 1997).

In order to test our three hypotheses, we analyze the determinants for general volunteering (Models 1-4). Table 1 presents the findings of our multi-level estimations. Regarding our first hypothesis, our models suggest that personal experiences of 
economic hardship significantly decrease the likelihood of volunteering in associations. If citizens in the 27 European societies have problems paying their bills at the end of the month, they are less likely to volunteer. In doing so, the effects seem to be very robust, even if we include variables on the country level. Contrary to the individual level, economic macro variables do not influence volunteering (Model 2). The GDP growth per capita, social expenditures and the unemployment rate are not significantly related to the likelihood to volunteer. In addition, there is no significant effect between East and West Europe. Moreover, the models show that men are more likely to volunteer in associations than women. In addition, we find that more educated citizens volunteer more often than individuals with a lower education. Moreover, citizens that live in a rural area or are married are also more active in voluntary associations. Furthermore, the household size has a positive and significant effect on voluntary work. Finally, the occupation status reveals a certain impact on volunteering. In comparison to self-employed citizens, white- and blue-collar workers as well as unemployed citizens are significantly less likely to volunteer. The lower the occupational status, the stronger the negative effect. ${ }^{7}$

- Table 1 around here-

As argued above, it is plausible to presume that the impact of economic hardship on people's volunteering behavior is moderated by the individual's level of education. This can be tested by modeling an interaction between economic hardship and education, thus testing hypothesis 2 . The results are shown in model 3 . The interaction term is statistically significant, indicating that higher levels of education are related to a reduced effect of economic hardship on volunteering. In other words: the negative relationship between economic hardship and volunteering is more powerful among those individuals who show lower levels of human capital than for highly educated individuals. Figure 2 shows the respective average marginal effects of economic hardship for the level of education. If citizens experience economic hardship, they are less likely to volunteer in comparison

\footnotetext{
7 In addition, we have also estimated cross-level interactions between the two economic variables, economic hardship and GDP growth. However, this interaction effect is not significant and does not influence our results. This analysis is not reported here but is available upon request.
} 
to when they do not have difficulties to pay their bills by the end of the month. However, this significant difference disappears for those citizens who have a high level of education. It seems that citizens with a higher education feel a higher need to fulfill an obligation towards the society, even if they have problems to pay their bills at the end of the month. ${ }^{8}$

\section{-Figure 2 around here-}

As a next step, in our last analyses shown in Table 2, the focus shifts to the probability of choosing a specific kind of formal volunteering (i.e. Olson vs. Putnam-Groups). First, the models show that the determinants vary strongly across the voluntary associations. While men are more likely to volunteer in sport, union, professional, and political associations, women engage more often for the community and charities. In addition, older individuals will more likely volunteer for communities and charities but less likely in sport and professional groups. Moreover, education, rural areas, and marriage have a positive effect for almost all associative groups, with the exceptions of community groups (no effect for rural), unions (no effect for rural and marriage) and professional groups (no effect for rural). Only household size is related significantly with engaging in sport groups. Self-employed citizens a more likely to volunteer in sports, charity, professional and to some extent in party organizations than white- and blue collars, as well as unemployed citizens. ${ }^{9}$

- Table 2 and Table 3 around here-

\footnotetext{
8 Although the figure provides evidence that the increase of education can diminish the effect of economic hardship on volunteering, we have to be careful in interpreting this result. On the one hand, the effect of economic hardship is only significant for lower and middle levels of education due to the reduced number of citizens with a high education. On the other hand, we estimated the same interaction for the different occupation status (model 4). Neither the interaction terms nor the individual variables are significant, with the exception of unemployed individuals with a higher education. This supports our theoretical argument that the interaction of economic hardship and education is not underlaid by class differences. Nevertheless, the occupation status seems to be important for volunteering.

9 White collars are not significantly less likely to volunteer in political parties than self-employed respondents.
} 
More important, we find evidence that the negative effect of individual economic hardship on volunteering does not apply for Olson-Groups. While the likelihood to volunteer decreases for Putnam-Groups in the area of sport, community, and charity, we cannot observe a link between personal economic hardship and the engagement in unions, professional, and political groups. In contrast, individuals are even more likely to engage for professional and political groups if they personally experience economic hardship, albeit these effects are not significant. Furthermore, interaction effects between human and economic capital are also only significant for Putnam-Groups. The effect of individual economic hardship on volunteering in Putnam-Groups decreases in magnitude with increasing levels of education. Regarding our variables on the second level, the models support the findings from the previous models. Country level factors are only marginal related to associational volunteering. The GDP growth and a rising unemployment rate influences volunteering in political organizations, while a higher social expenditure increases the chances that citizens engage in unions.

To sum up, we can argue that economic hardship is negatively linked to the motivation for individuals to volunteer, but this relation can be attenuated with personal resources, such as education. In addition, the models provide evidence that the economic deprivation does not impact volunteering in all associations equally. Thus, we argue that individuals rather focus on voluntary associations from which they expect a reward in times of economic hardship.

In order to evaluate the robustness of our results, we conducted a variety of sensitivity analyses not documented here. We re-estimated the models several times, each time excluding one country and its respondents. Although this kind of manual jackknifing represents a strict test for influential cases (excluding in some cases over thousand respondents), the economic hardship variable remains significant in all 27 separate models. Following the argumentation of van der Meer et al. $(2010,176)$, however, the exclusion of single level-two units does not always suffice to detect a cluster of influential cases. We therefore alternatively computed numeric diagnostics in order to detect potential influential 
cases. In doing so, we calculated DFBETAs ${ }^{10}$ for each fixed parameter in our overall model containing our independent variables. The analyses reveal that there are two countries with critical values for our significant individual variable (the Netherlands, Sweden). As a consequence, we included a dummy variable for individuals living in one of those two countries into our model. The results reveal that the relationship between the individual economic hardship and volunteering engagement remains statistically significant (see Table A2 in the Appendix).

\section{Conclusion}

How does economic hardship affect social capital in Europe? In this study, we have investigated to what extent personal experiences of economic hardship have an impact on civic engagement. We have presented data from the Eurobarometer 75.2. in 2011, which was conducted shortly after the peak of the financial crisis in Europe. The empirical analysis suggests that economic hardship partially affected the likelihood of associational volunteering. Citizens who experience individual economic hardship are less likely to engage in a voluntary association. However, a high level of education regulates this effect: the negative effect of individual economic hardship on volunteering is weaker for citizens with a high education. Citizens with higher education are not less likely to volunteer if they experience economic hardship. In general, these effects indicate that personal resources (e.g. money, education) are important for civic engagement, which supports the civic voluntarism model (Brady et al., 1995; Verba et al., 1995). Moreover, our models provide evidence that citizens will be less likely to engage in solidarity Putnam-Groups from which they cannot directly obtain an economic benefit.

These findings on the citizens' associational activity in response to economic hardship have important implications for the analysis of social capital and policy-making. First,

${ }^{10}$ DFBETAs measures how much impact each observation has on a particular predictor. The DFBETA is the difference between the regression coefficient calculated for all of the data and the regression coefficient calculated with the observation deleted, scaled by the standard error calculated with the observation deleted (Belsley et al. 2005: 73). 
our results underline the important distinction with respect to different sorts of capital in forming social capital. Moreover, the dynamics of economic resources and human capital are crucial for the understanding of the development of volunteering in different associations such as Putnam- and Olson-Groups. In this regard, both economic and human capital are likely to have equally intertwined effects for other areas of the social fabric of the society. Secondly, the findings point out to direct policy implications. Volunteering citizens react vulnerable towards economic hardship, if they lack in human capital, in particular education. This means that policy makers should be worthwhile on a functioning education system, as education can offset economic hard times in order to maintain the balance of the social fabric. This is especially an important message, since politicians often have the tendency to reduce the state's budget in economic difficult times, even in the education sector.

It has to be noted, however, that our study has also some limitations. First, although we show that economic hardship is negatively related to formal volunteering as a cornerstone of social capital, it is unclear whether the membership in voluntary associations really captures the essence of social capital in hard times. It seems likely that citizens will not necessarily engage in voluntary associations in order to show their solidarity with less privileged citizens. Formal volunteering certainly accounts for an enormous portion of altruistic behavior in society, but concentrating entirely on associational volunteering "leaves out much of the informal or unorganized 'Good Samaritan' activities taking place in daily life without the mediation of formal groups" (Lim \& Laurence, 2015, 324). In this respect, Sotiropoulos (2014), for example, shows that the level of donations has increased during the economic crisis in Greece. Individuals can also help by donating food or providing other life-support supplies to less fortunate individuals outside voluntary associations.

Another problem concerns causal inference. A problem of our analysis is that we do not know when an individual started to engage in voluntary activities. This means that many decisions to volunteer were made before the measurement of our independent variables. This has several consequences. First, we cannot make any statements about 
causal relationships, only about correlations. If citizens with economic hardship have a lower propensity to volunteer, this can mean different things: (1) economic hardship prevents volunteering, (2) volunteering increases the likelihood to experience economic hardship, or (3) a third factor not accounted for in our analyses explains both economic hardship and volunteering. Purely based on our analysis, we cannot know which of the three applies in our case. While we made a strong argument for the first point, there are some considerations that provides arguments against the latter two aspects. On the one hand, several studies argue that volunteering does not lead to economic hardship, yet improves the economic situation of a citizen (Hackl et al., 2007; Ruiter \& de Graff 2008; Benenson \& Stagg, 2016). On the other hand, we included all factors that prior studies have shown to be relevant for engaging in volunteering activities (Wilson, 2012). A number of other variables discussed in the literature were included to control for other potential determinants of volunteering and in order to address the possible non-random exposure to economic hardship.

Third, and related to prior limitation, our data only allows cross-sectional and not longitudinal analyses. The fact that we only have a cross-sectional snapshot of the situation means that we cannot make any statements about other time points unless we make a rather strong assumption. The assumption is that the relationships between different indicators and the differences of the indicators across citizens and states remain constant over time. Hence, since we only investigate a specific point of time, which is why we have to be careful in drawing more general conclusions. Nevertheless, we are convinced that the situation in the year 2011 is a good moment of time in order to illustrate how economic hardship affects the voluntary life, since it is situated during the economic crisis in Europe. Moreover, our cross-sectional approach provides other methodological advantages. Our descriptive analyses in this study show varying levels of volunteering the EU-27, which clearly points out the relevance for a comparative analysis. While most existing studies on economic hardship and social capital are limited in their geographical scope, we have been able to provide a unique cross-national analysis. This way we not only complement previous single country studies and put them in a broader perspective but are also able reconcile some of the inconclusive findings so far. 
Nevertheless, we recommend that future research examines whether this relationship is time-specific by employ longitudinal or experimental research designs.

Our findings point out the potential to study the economic crisis in order to understand the decline of voluntary engagement. Although the Eurobarometer data set is limited in various aspects, the study has important implications for social capital, since financial downturns is able to have a severe impact on civic engagement. Depending on the resources of an individual, citizens will be more or less likely to engage in volunteer activities in their society. Nevertheless, our analyses also suggest that the key to a vibrant civil society may lie in human capital investments. Not only does education have a strong und positive direct effect on volunteering, but it also weakens the negative impact of economic hardship on social capital. However, further research needs to explore how the change of those resources develop, and how they shape the motivation for civic engagement. We are convinced that this analysis might be the first step in order to study the extent of this development. 


\section{Appendix}

Figure 1: Percentage of Volunteers \& Citizens with Economic Hardship in the EU-27

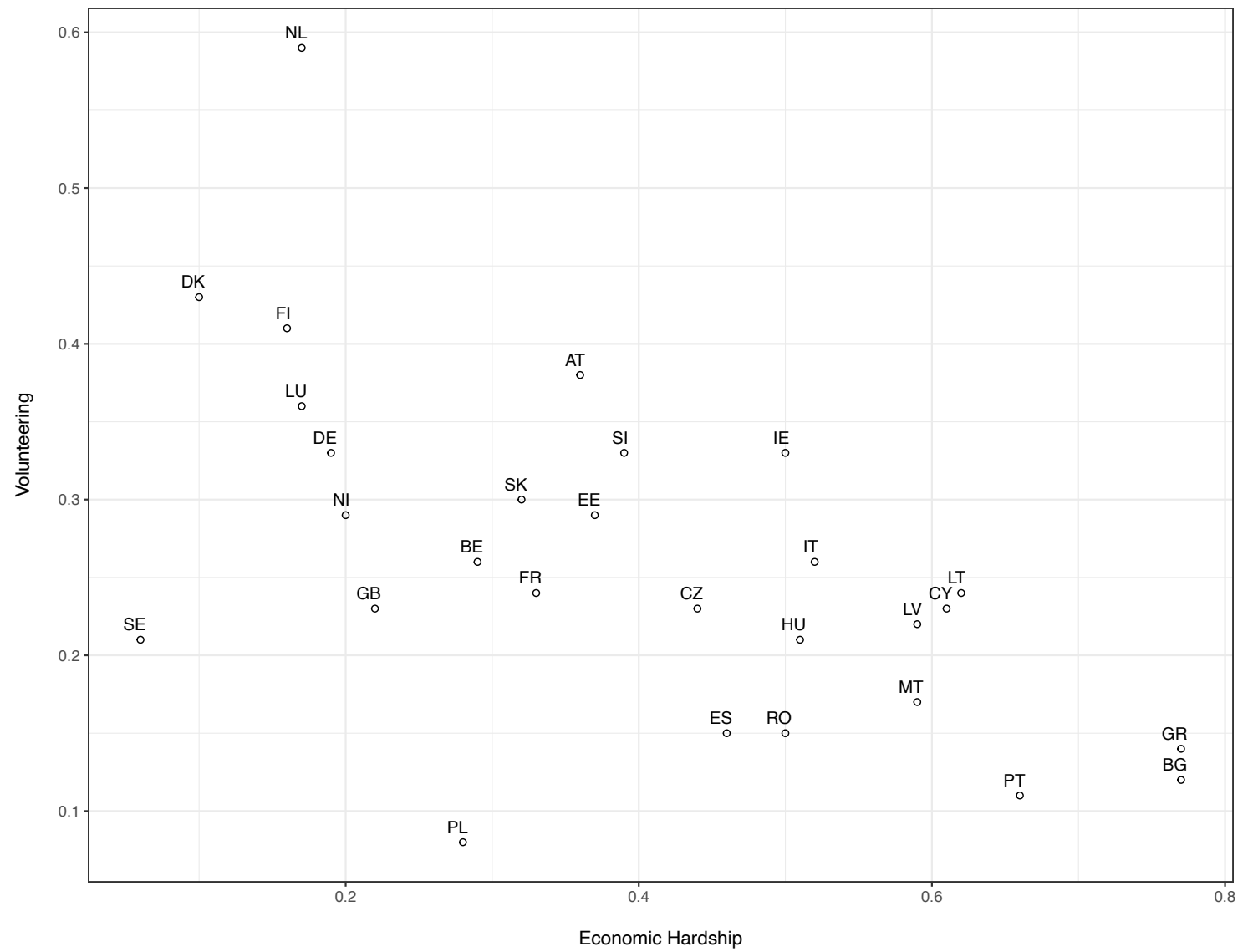

Note: The figure shows the aggregated levels of economic hardship and volunteering across the EU-27. Both variables are dichotomized. Reading example: In Romania, $15 \%$ of the respondents engage in voluntary activities, while $50 \%$ of the same group experience economic hardship. 
Table 1: Determinants of Social Capital (Associational Volunteering) in 27 EU-Countries

\begin{tabular}{|c|c|c|c|c|}
\hline & $\begin{array}{l}\text { Individual } \\
\text { Model } \\
\text { (1) }\end{array}$ & $\begin{array}{l}\text { Country } \\
\text { Model } \\
\text { (2) }\end{array}$ & $\begin{array}{c}\text { Hardship Interaction } \\
\text { Model } \\
\text { (3) }\end{array}$ & $\begin{array}{c}\text { Class Interaction } \\
\text { Model } \\
(4)\end{array}$ \\
\hline Male & $\begin{array}{l}0.071^{* *} \\
(0.032)\end{array}$ & $\begin{array}{l}0.071^{* *} \\
(0.032)\end{array}$ & $\begin{array}{l}0.072^{* *} \\
(0.032)\end{array}$ & $\begin{array}{l}0.069^{* *} \\
(0.032)\end{array}$ \\
\hline Age & $\begin{array}{l}0.002 \\
(0.001)\end{array}$ & $\begin{array}{l}0.002 * \\
(0.001)\end{array}$ & $\begin{array}{l}0.002^{*} \\
(0.001)\end{array}$ & $\begin{array}{l}0.002^{*} \\
(0.001)\end{array}$ \\
\hline Education & $\begin{array}{l}0.079^{* * *} \\
(0.005)\end{array}$ & $\begin{array}{l}0.077^{* * *} \\
(0.005)\end{array}$ & $\begin{array}{l}0.071^{* * *} \\
(0.005)\end{array}$ & $\begin{array}{l}0.077^{* * *} \\
(0.011)\end{array}$ \\
\hline Rural & $\begin{array}{l}0.251^{* * *} \\
(0.037)\end{array}$ & $\begin{array}{l}0.255^{* * *} \\
(0.038)\end{array}$ & $\begin{array}{l}0.255^{* * *} \\
(0.038)\end{array}$ & $\begin{array}{l}0.255^{* * *} \\
(0.038)\end{array}$ \\
\hline Married & $\begin{array}{l}0.140^{* * *} \\
(0.036)\end{array}$ & $\begin{array}{l}0.130^{* * *} \\
(0.037)\end{array}$ & $\begin{array}{l}0.131^{* * *} \\
(0.037)\end{array}$ & $\begin{array}{l}0.130^{* * *} \\
(0.037)\end{array}$ \\
\hline Household Size & $\begin{array}{l}0.048^{* * *} \\
(0.014)\end{array}$ & $\begin{array}{l}0.051^{* * *} \\
(0.015)\end{array}$ & $\begin{array}{l}0.051^{* * *} \\
(0.015)\end{array}$ & $\begin{array}{l}0.051^{* * *} \\
(0.015)\end{array}$ \\
\hline White Collar & $\begin{array}{l}-0.157^{* * *} \\
(0.050)\end{array}$ & $\begin{array}{l}-0.154^{* * *} \\
(0.051)\end{array}$ & $\begin{array}{l}-0.154^{* * *} \\
(0.051)\end{array}$ & $\begin{array}{l}-0.142 \\
(0.242)\end{array}$ \\
\hline Blue Collar & $\begin{array}{l}-0.175^{* * *} \\
(0.058)\end{array}$ & $\begin{array}{l}-0.197^{* * *} \\
(0.059)\end{array}$ & $\begin{array}{l}-0.197^{* * *} \\
(0.059)\end{array}$ & $\begin{array}{l}0.046 \\
(0.299)\end{array}$ \\
\hline Unemployed & $\begin{array}{l}-0.244^{* * *} \\
(0.064)\end{array}$ & $\begin{array}{l}-0.240^{* * *} \\
(0.065)\end{array}$ & $\begin{array}{l}-0.236^{* * *} \\
(0.065)\end{array}$ & $\begin{array}{l}-0.644^{* *} \\
(0.311)\end{array}$ \\
\hline Economic Hardship & $\begin{array}{l}-0.076^{* *} \\
(0.036)\end{array}$ & $\begin{array}{l}-0.076^{* *} \\
(0.037)\end{array}$ & $\begin{array}{l}-0.427^{* *} \\
(0.175)\end{array}$ & $\begin{array}{l}-0.076^{* *} \\
(0.037)\end{array}$ \\
\hline $\begin{array}{l}\text { Economic Hardship } \times \\
\text { Education }\end{array}$ & & & $\begin{array}{l}0.019^{* *} \\
(0.009)\end{array}$ & \\
\hline White Collar $\times$ Education & & & & $\begin{array}{l}-0.001 \\
(0.012)\end{array}$ \\
\hline Blue Collar $\times$ Education & & & & $\begin{array}{l}-0.013 \\
(0.015)\end{array}$ \\
\hline Unemployed $\times$ Education & & & & $\begin{array}{l}0.023 \\
(0.016)\end{array}$ \\
\hline West Europe & & $\begin{array}{l}0.141 \\
(0.328)\end{array}$ & $\begin{array}{l}0.145 \\
(0.327)\end{array}$ & $\begin{array}{l}0.149 \\
(0.327)\end{array}$ \\
\hline GDP Growth & & $\begin{array}{l}-0.021 \\
(0.019)\end{array}$ & $\begin{array}{l}-0.021 \\
(0.019)\end{array}$ & $\begin{array}{l}-0.021 \\
(0.019)\end{array}$ \\
\hline Social Expenditure & & $\begin{array}{l}0.019 \\
(0.032)\end{array}$ & $\begin{array}{l}0.019 \\
(0.032)\end{array}$ & $\begin{array}{l}0.019 \\
(0.032)\end{array}$ \\
\hline Unemployment & & $\begin{array}{l}-0.048 \\
(0.039)\end{array}$ & $\begin{array}{l}-0.048 \\
(0.039)\end{array}$ & $\begin{array}{l}-0.048 \\
(0.039)\end{array}$ \\
\hline Constant & $\begin{array}{l}0.329^{* * *} \\
(0.089)\end{array}$ & $\begin{array}{l}0.244^{* * *} \\
(0.069)\end{array}$ & $\begin{array}{l}0.243^{* * *} \\
(0.069)\end{array}$ & $\begin{array}{l}0.242^{* * *} \\
(0.069)\end{array}$ \\
\hline $\mathrm{N}$ & 22,958 & 22,185 & 22,185 & 22,185 \\
\hline Log. Likelihood & $-16,091.15$ & $-15,475.89$ & $-15,473.79$ & $-15,473.49$ \\
\hline Wald chi2 & 472.87 & 449.01 & 451.77 & 452.50 \\
\hline $\mathrm{p}>\operatorname{chi} 2$ & 0.000 & 0.000 & 0.000 & 0.000 \\
\hline AIC & 32208.30 & 30987.79 & 30985.58 & 30988.97 \\
\hline $\mathrm{BIC}$ & 32312.84 & 31131.92 & 31137.71 & 31157.12 \\
\hline
\end{tabular}

Note: Results are from a multilevel mixed-effects ordered logistic regression. Regression coefficients shown with robust standard errors in parentheses. ${ }^{*} \mathrm{p}<0.1{ }^{* *} \mathrm{p}<0.05,{ }^{* * *} \mathrm{p}<0.01$. Reference category for white collar, blue collar, and unemployed: Self-employed. 
Figure 2: Average Marginal Effects of Economic Hardship

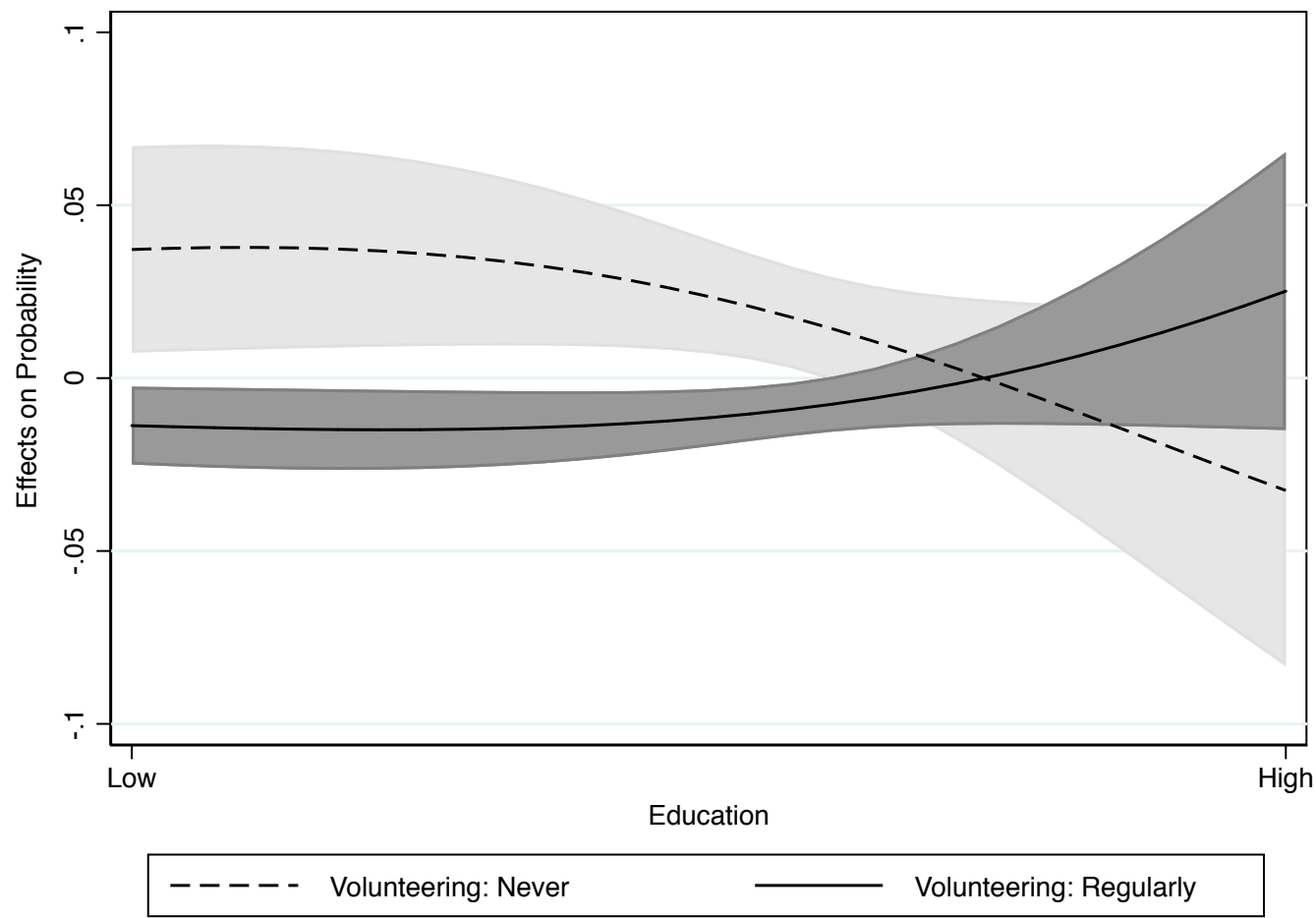

Note: The figure shows the average marginal effects of economic hardship with $95 \%$ confidence interval for the level of education (0: low education; 30: high education). 
Table 2: Determinants of Volunteering in Putnam-Groups (Sport, Community, Charity)

\begin{tabular}{|c|c|c|c|c|c|c|}
\hline & \multicolumn{2}{|c|}{ Sport } & \multicolumn{2}{|c|}{ Community } & \multicolumn{2}{|c|}{ Charity } \\
\hline & (5) & (6) & (7) & (8) & (9) & (10) \\
\hline Male & $\begin{array}{c}0.880^{* * *} \\
(0.066)\end{array}$ & $\begin{array}{l}0.887^{* * *} \\
(0.066)\end{array}$ & $\begin{array}{l}-0.521^{* * *} \\
(0.118)\end{array}$ & $\begin{array}{l}-0.512^{* * *} \\
(0.118)\end{array}$ & $\begin{array}{l}-0.395^{* * *} \\
(0.070)\end{array}$ & $\begin{array}{l}-0.388^{* * *} \\
(0.071)\end{array}$ \\
\hline Age & $\begin{array}{c}-0.015^{* * *} \\
(0.002)\end{array}$ & $\begin{array}{l}-0.015^{* * *} \\
(0.002)\end{array}$ & $\begin{array}{l}0.013^{* * *} \\
(0.004)\end{array}$ & $\begin{array}{l}0.014^{* * *} \\
(0.004)\end{array}$ & $\begin{array}{l}0.006^{* *} \\
(0.003)\end{array}$ & $\begin{array}{l}0.007^{* *} \\
(0.003)\end{array}$ \\
\hline Education & $\begin{array}{c}0.068^{* * *} \\
(0.009)\end{array}$ & $\begin{array}{l}0.057^{* * * *} \\
(0.010)\end{array}$ & $\begin{array}{l}0.087^{* * *} \\
(0.016)\end{array}$ & $\begin{array}{l}0.068^{* * *} \\
(0.018)\end{array}$ & $\begin{array}{l}0.103^{* * *} \\
(0.009)\end{array}$ & $\begin{array}{l}0.089^{* * * *} \\
(0.011)\end{array}$ \\
\hline Rural & $\begin{array}{c}0.498^{* * *} \\
(0.079)\end{array}$ & $\begin{array}{l}0.496^{* * *} \\
(0.079)\end{array}$ & $\begin{array}{l}0.209 \\
(0.133)\end{array}$ & $\begin{array}{l}0.208 \\
(0.133)\end{array}$ & $\begin{array}{l}0.196^{* *} \\
(0.080)\end{array}$ & $\begin{array}{l}0.194^{* *} \\
(0.080)\end{array}$ \\
\hline Married & $\begin{array}{c}0.271^{* * *} \\
(0.072)\end{array}$ & $\begin{array}{l}0.273^{* * *} \\
(0.072)\end{array}$ & $\begin{array}{l}0.441^{* * *} \\
(0.131)\end{array}$ & $\begin{array}{l}0.447^{* * *} \\
(0.131)\end{array}$ & $\begin{array}{l}0.213^{* * *} \\
(0.077)\end{array}$ & $\begin{array}{l}0.216^{* * *} \\
(0.077)\end{array}$ \\
\hline Household Size & $\begin{array}{c}0.157^{* * *} \\
(0.026)\end{array}$ & $\begin{array}{l}0.158^{* * *} \\
(0.026)\end{array}$ & $\begin{array}{l}-0.024 \\
(0.056)\end{array}$ & $\begin{array}{l}-0.024 \\
(0.056)\end{array}$ & $\begin{array}{l}-0.015 \\
(0.032)\end{array}$ & $\begin{array}{l}-0.015 \\
(0.032)\end{array}$ \\
\hline White Collar & $\begin{array}{c}-0.219^{* *} \\
(0.094)\end{array}$ & $\begin{array}{l}-0.219^{* *} \\
(0.094)\end{array}$ & $\begin{array}{l}-0.162 \\
(0.179)\end{array}$ & $\begin{array}{l}-0.168 \\
(0.179)\end{array}$ & $\begin{array}{l}-0.227^{* *} \\
(0.108)\end{array}$ & $\begin{array}{l}-0.228^{* *} \\
(0.108)\end{array}$ \\
\hline Blue Collar & $\begin{array}{c}-0.247^{* *} \\
(0.107)\end{array}$ & $\begin{array}{l}-0.246^{* *} \\
(0.107)\end{array}$ & $\begin{array}{l}0.057 \\
(0.208)\end{array}$ & $\begin{array}{l}0.053 \\
(0.207)\end{array}$ & $\begin{array}{l}-0.233^{*} \\
(0.127)\end{array}$ & $\begin{array}{l}-0.232^{*} \\
(0.126)\end{array}$ \\
\hline Unemployed & $\begin{array}{c}-0.515^{* * *} \\
(0.134)\end{array}$ & $\begin{array}{l}-0.502^{* * *} \\
(0.134)\end{array}$ & $\begin{array}{l}-0.264 \\
(0.228)\end{array}$ & $\begin{array}{l}-0.251 \\
(0.228)\end{array}$ & $\begin{array}{l}-0.274^{* *} \\
(0.136)\end{array}$ & $\begin{array}{l}-0.263^{*} \\
(0.136)\end{array}$ \\
\hline Economic Hardship & $\begin{array}{c}-0.168^{* *} \\
(0.075)\end{array}$ & $\begin{array}{l}-1.104^{* * *} \\
(0.383)\end{array}$ & $\begin{array}{l}0.114 \\
(0.129)\end{array}$ & $\begin{array}{l}-1.033^{*} \\
(0.566)\end{array}$ & $\begin{array}{l}-0.074 \\
(0.079)\end{array}$ & $\begin{array}{l}-1.016^{* * *} \\
(0.365)\end{array}$ \\
\hline Economic Hardship $\times$ Education & & $\begin{array}{l}0.049^{* *} \\
(0.020)\end{array}$ & & $\begin{array}{l}0.061^{* *} \\
(0.029)\end{array}$ & & $\begin{array}{l}0.049^{* * *} \\
(0.019)\end{array}$ \\
\hline West Europe & $\begin{array}{c}-0.135 \\
(0.633)\end{array}$ & $\begin{array}{c}-0.123 \\
(0.631)\end{array}$ & $\begin{array}{l}0.538 \\
(0.379)\end{array}$ & $\begin{array}{l}0.540 \\
(0.377)\end{array}$ & $\begin{array}{l}0.432 \\
(0.382)\end{array}$ & $\begin{array}{c}0.437 \\
(0.381)\end{array}$ \\
\hline GDP Growth & $\begin{array}{c}-0.027 \\
(0.038)\end{array}$ & $\begin{array}{l}-0.027 \\
(0.037)\end{array}$ & $\begin{array}{l}-0.026 \\
(0.022)\end{array}$ & $\begin{array}{l}-0.026 \\
(0.022)\end{array}$ & $\begin{array}{l}-0.022 \\
(0.023)\end{array}$ & $\begin{array}{l}-0.022 \\
(0.022)\end{array}$ \\
\hline Social Expenditure & $\begin{array}{l}0.082 \\
(0.062)\end{array}$ & $\begin{array}{l}0.081 \\
(0.061)\end{array}$ & $\begin{array}{l}0.008 \\
(0.036)\end{array}$ & $\begin{array}{l}0.009 \\
(0.036)\end{array}$ & $\begin{array}{l}-0.009 \\
(0.037)\end{array}$ & $\begin{array}{l}-0.008 \\
(0.037)\end{array}$ \\
\hline Unemployment & $\begin{array}{c}-0.099 \\
(0.077)\end{array}$ & $\begin{array}{l}-0.099 \\
(0.076)\end{array}$ & $\begin{array}{l}-0.049 \\
(0.045)\end{array}$ & $\begin{array}{l}-0.050 \\
(0.045)\end{array}$ & $\begin{array}{l}-0.023 \\
(0.046)\end{array}$ & $\begin{array}{l}-0.024 \\
(0.045)\end{array}$ \\
\hline Constant & $\begin{array}{c}0.898^{* * *} \\
(0.276)\end{array}$ & $\begin{array}{l}0.891^{* * *} \\
(0.274)\end{array}$ & $\begin{array}{l}0.228^{* * *} \\
(0.086)\end{array}$ & $\begin{array}{l}0.225^{* * *} \\
(0.085)\end{array}$ & $\begin{array}{l}0.304^{* * *} \\
(0.096)\end{array}$ & $\begin{array}{l}0.302^{* * *} \\
(0.096)\end{array}$ \\
\hline$\overline{\mathrm{N}}$ & 17758 & 17758 & 16834 & 16834 & 17479 & 17479 \\
\hline Log. Likelihood & -4703.41 & -4700.30 & -1801.24 & -1799.07 & -4237.57 & -4234.06 \\
\hline Wald chi2 & 501.54 & 504.10 & 85.87 & 90.49 & 180.90 & 186.18 \\
\hline $\mathrm{p}>\mathrm{chi} 2$ & 0.000 & 0.000 & 0.000 & 0.000 & 0.000 & 0.000 \\
\hline AIC & 9442.82 & 9438.61 & 3638.49 & 3636.15 & 8511.15 & 8506.13 \\
\hline BIC & 9582.94 & 9586.51 & 3777.65 & 3783.04 & 8650.98 & 8653.74 \\
\hline
\end{tabular}

Note: Results are from a multilevel mixed-effects ordered logistic regression. Regression coefficients shown with robust standard errors in parentheses. ${ }^{*} \mathrm{p}<0.1$, $^{* *} \mathrm{p}<0.05, * * * \mathrm{p}<0.01$. Reference category for white collar, blue collar, and unemployed: Self-employed. 
Table 3: Determinants of Volunteering in Olson-Groups (Union, Professional, Party)

\begin{tabular}{|c|c|c|c|c|c|c|}
\hline & \multicolumn{2}{|c|}{ Union } & \multicolumn{2}{|c|}{ Professional } & \multicolumn{2}{|c|}{ Party } \\
\hline & $(11)$ & (12) & (13) & (14) & $(15)$ & $(16)$ \\
\hline Male & $\begin{array}{c}0.355^{* * *} \\
(0.131)\end{array}$ & $\begin{array}{l}0.357^{* * *} \\
(0.131)\end{array}$ & $\begin{array}{l}0.267^{* *} \\
(0.127)\end{array}$ & $\begin{array}{l}0.262^{* *} \\
(0.127)\end{array}$ & $\begin{array}{l}0.676^{* * *} \\
(0.149)\end{array}$ & $\begin{array}{l}0.673^{* * *} \\
(0.149)\end{array}$ \\
\hline Age & $\begin{array}{c}-0.001 \\
(0.005)\end{array}$ & $\begin{array}{l}-0.001 \\
(0.005)\end{array}$ & $\begin{array}{l}-0.010^{* *} \\
(0.005)\end{array}$ & $\begin{array}{l}-0.010^{* *} \\
(0.005)\end{array}$ & $\begin{array}{l}0.004 \\
(0.005)\end{array}$ & $\begin{array}{l}0.004 \\
(0.005)\end{array}$ \\
\hline Education & $\begin{array}{c}0.083^{* * *} \\
(0.018)\end{array}$ & $\begin{array}{l}0.079^{* * *} \\
(0.021)\end{array}$ & $\begin{array}{l}0.124^{* * *} \\
(0.018)\end{array}$ & $\begin{array}{l}0.133^{* * *} \\
(0.020)\end{array}$ & $\begin{array}{l}0.121^{* * *} \\
(0.018)\end{array}$ & $\begin{array}{l}0.127^{* * *} \\
(0.020)\end{array}$ \\
\hline Rural & $\begin{array}{l}0.143 \\
(0.152)\end{array}$ & $\begin{array}{l}0.143 \\
(0.152)\end{array}$ & $\begin{array}{l}0.106 \\
(0.143)\end{array}$ & $\begin{array}{l}0.106 \\
(0.143)\end{array}$ & $\begin{array}{l}0.326^{* *} \\
(0.166)\end{array}$ & $\begin{array}{l}0.326^{* *} \\
(0.166)\end{array}$ \\
\hline Married & $\begin{array}{l}0.134 \\
(0.147)\end{array}$ & $\begin{array}{l}0.135 \\
(0.147)\end{array}$ & $\begin{array}{l}0.429^{* * *} \\
(0.148)\end{array}$ & $\begin{array}{l}0.428^{* * *} \\
(0.148)\end{array}$ & $\begin{array}{l}0.481^{* * *} \\
(0.167)\end{array}$ & $\begin{array}{l}0.479^{* * *} \\
(0.167)\end{array}$ \\
\hline Household Size & $\begin{array}{l}0.046 \\
(0.058)\end{array}$ & $\begin{array}{l}0.046 \\
(0.058)\end{array}$ & $\begin{array}{l}-0.010 \\
(0.058)\end{array}$ & $\begin{array}{l}-0.010 \\
(0.058)\end{array}$ & $\begin{array}{l}-0.038 \\
(0.069)\end{array}$ & $\begin{array}{l}-0.037 \\
(0.069)\end{array}$ \\
\hline White Collar & $\begin{array}{l}0.025 \\
(0.209)\end{array}$ & $\begin{array}{l}0.024 \\
(0.209)\end{array}$ & $\begin{array}{l}-0.367^{* *} \\
(0.178)\end{array}$ & $\begin{array}{l}-0.365^{* *} \\
(0.178)\end{array}$ & $\begin{array}{l}-0.205 \\
(0.195)\end{array}$ & $\begin{array}{l}-0.203 \\
(0.195)\end{array}$ \\
\hline Blue Collar & $\begin{array}{l}0.076 \\
(0.234)\end{array}$ & $\begin{array}{l}0.076 \\
(0.234)\end{array}$ & $\begin{array}{l}-0.467^{* *} \\
(0.210)\end{array}$ & $\begin{array}{l}-0.468^{* *} \\
(0.210)\end{array}$ & $\begin{array}{l}-0.441^{*} \\
(0.246)\end{array}$ & $\begin{array}{l}-0.440^{*} \\
(0.246)\end{array}$ \\
\hline Unemployed & $\begin{array}{c}-0.254 \\
(0.275)\end{array}$ & $\begin{array}{l}-0.252 \\
(0.275)\end{array}$ & $\begin{array}{l}-1.105^{* * *} \\
(0.284)\end{array}$ & $\begin{array}{l}-1.114^{* * *} \\
(0.284)\end{array}$ & $\begin{array}{l}-0.701^{* *} \\
(0.318)\end{array}$ & $\begin{array}{l}-0.710^{* *} \\
(0.319)\end{array}$ \\
\hline Economic Hardship & $\begin{array}{l}0.173 \\
(0.143)\end{array}$ & $\begin{array}{l}-0.037 \\
(0.656)\end{array}$ & $\begin{array}{l}-0.042 \\
(0.143)\end{array}$ & $\begin{array}{l}0.575 \\
(0.702)\end{array}$ & $\begin{array}{c}0.206 \\
(0.165)\end{array}$ & $\begin{array}{l}0.714 \\
(0.747)\end{array}$ \\
\hline Economic Hardship $\times$ Education & & $\begin{array}{l}0.011 \\
(0.034)\end{array}$ & & $\begin{array}{l}-0.032 \\
(0.036)\end{array}$ & & $\begin{array}{l}-0.026 \\
(0.038)\end{array}$ \\
\hline West Europe & $\begin{array}{c}-0.264 \\
(0.512)\end{array}$ & $\begin{array}{l}-0.263 \\
(0.512)\end{array}$ & $\begin{array}{l}-0.222 \\
(0.422)\end{array}$ & $\begin{array}{l}-0.225 \\
(0.422)\end{array}$ & $\begin{array}{l}0.522 \\
(0.525)\end{array}$ & $\begin{array}{l}0.517 \\
(0.527)\end{array}$ \\
\hline GDP Growth & $\begin{array}{c}-0.033 \\
(0.030)\end{array}$ & $\begin{array}{l}-0.033 \\
(0.030)\end{array}$ & $\begin{array}{l}-0.003 \\
(0.025)\end{array}$ & $\begin{array}{l}-0.003 \\
(0.025)\end{array}$ & $\begin{array}{l}-0.047 \\
(0.032)\end{array}$ & $\begin{array}{l}-0.047 \\
(0.032)\end{array}$ \\
\hline Social Expenditure & $\begin{array}{c}0.104^{* *} \\
(0.052)\end{array}$ & $\begin{array}{l}0.104^{* *} \\
(0.052)\end{array}$ & $\begin{array}{l}0.050 \\
(0.042)\end{array}$ & $\begin{array}{l}0.050 \\
(0.042)\end{array}$ & $\begin{array}{l}-0.019 \\
(0.051)\end{array}$ & $\begin{array}{l}-0.019 \\
(0.051)\end{array}$ \\
\hline Unemployment & $\begin{array}{c}-0.070 \\
(0.059)\end{array}$ & $\begin{array}{l}-0.070 \\
(0.059)\end{array}$ & $\begin{array}{l}-0.037 \\
(0.050)\end{array}$ & $\begin{array}{l}-0.036 \\
(0.050)\end{array}$ & $\begin{array}{l}-0.133^{* *} \\
(0.065)\end{array}$ & $\begin{array}{l}-0.132^{* *} \\
(0.065)\end{array}$ \\
\hline Constant & $\begin{array}{c}0.408^{* *} \\
(0.182)\end{array}$ & $\begin{array}{l}0.409^{* *} \\
(0.182)\end{array}$ & $\begin{array}{l}0.275^{* *} \\
(0.120)\end{array}$ & $\begin{array}{l}0.276^{* *} \\
(0.120)\end{array}$ & $\begin{array}{l}0.439^{* *} \\
(0.185)\end{array}$ & $\begin{array}{l}0.444^{* *} \\
(0.187)\end{array}$ \\
\hline $\begin{array}{l}\mathrm{N} \\
\text { Log. Likelihood }\end{array}$ & $\begin{array}{l}16,746 \\
-1423.76\end{array}$ & $\begin{array}{l}16,746 \\
-1423.71\end{array}$ & $\begin{array}{l}16,760 \\
-1484.80\end{array}$ & $\begin{array}{l}16,760 \\
-1484.40\end{array}$ & $\begin{array}{c}16,715 \\
-1213.03\end{array}$ & $\begin{array}{l}16,715 \\
-1212.78\end{array}$ \\
\hline Wald chi2 & 55.34 & 55.47 & 114.32 & 116.38 & 124.33 & 124.96 \\
\hline $\mathrm{p}>\mathrm{chi} 2$ & 0.000 & 0.000 & 0.000 & 0.000 & 0.000 & 0.000 \\
\hline AIC & 2883.52 & 2885.41 & 3005.60 & 3006.80 & 2462.06 & 2463.57 \\
\hline $\mathrm{BIC}$ & 3022.59 & 3032.20 & 3144.68 & 3153.60 & 2601.09 & 2610.32 \\
\hline
\end{tabular}

Note: Results are from a multilevel mixed-effects ordered logistic regression. Regression coefficients shown with robust standard errors in parentheses. ${ }^{*} \mathrm{p}<0.1,{ }^{* *} \mathrm{p}<0.05,{ }^{* * *} \mathrm{p}<0.01$. Reference category for white collar, blue collar, and unemployed: self-employed. 
Table A1: Variables, Operationalization, Descriptive Statistics and Source

\begin{tabular}{|c|c|c|c|c|c|}
\hline \multirow[t]{2}{*}{ Variable } & \multirow[t]{2}{*}{ Operationalization } & \multicolumn{4}{|c|}{ Descriptive Statistics } \\
\hline & & Mean & Std. Dev & Min & Max \\
\hline \multicolumn{6}{|l|}{ Dependent Variable } \\
\hline Volunteering & $\begin{array}{l}\text { Volunteering activity: Ordinal variable: } 0= \\
\text { never; } 1=\text { Yes, on occasional basis; } 2=\text { Yes, on } \\
\text { regular basis }\end{array}$ & 0.37 & 0.66 & 0 & 2 \\
\hline \multicolumn{6}{|c|}{ Independent Variables } \\
\hline \multicolumn{6}{|l|}{ Level 1 (Individual) } \\
\hline Male & $\begin{array}{l}\text { Sex of respondent: Dichotomous variable: } 0 \\
=\text { female; } 1=\text { male }\end{array}$ & 0.46 & 0.50 & 0 & 1 \\
\hline Age & $\begin{array}{l}\text { Age of respondent: "How old are you?"; } \\
\text { continuous variable }\end{array}$ & 48.36 & 18.20 & 15 & 96 \\
\hline Education & $\begin{array}{l}\text { Education of respondent: "How old were you } \\
\text { when you stopped full-time education?"; } \\
\text { continuous variable }\end{array}$ & 18.43 & 3.82 & 2 & 30 \\
\hline Rural & $\begin{array}{l}\text { Type of community of respondent: "Would you } \\
\text { say you live in a...?"; Dichotomous variable: } 0 \\
=\text { rural; } 1=\text { urban }\end{array}$ & 0.28 & 0.45 & 0 & 1 \\
\hline Marital Status & $\begin{array}{l}\text { Marital status of respondent: Dichotomous } \\
\text { variable: } 0=\text { not married; } 1=\text { married }\end{array}$ & 0.52 & 0.5 & 0 & 1 \\
\hline Household Size & $\begin{array}{l}\text { Household size of respondent: Categorial } \\
\text { variable: } 1=\text { one; }[\ldots] 7=\text { seven or more }\end{array}$ & 2.65 & 1.37 & 1 & 7 \\
\hline Occupation Status & $\begin{array}{l}\text { Respondent's occupation scale: Ordinal } \\
\text { variable: } 1=\text { self-employed; } 2=\text { white collar } \\
\text { (managers and other white collars); } 3=\text { blue } \\
\text { collar (manual workers); } 4=\text { unemployed } \\
\text { (house persons and unoccupied) }\end{array}$ & 2.44 & 0.89 & 1 & 4 \\
\hline $\begin{array}{l}\text { Economic } \\
\text { Hardship }\end{array}$ & $\begin{array}{l}\text { Respondent's difficulties paying bills: "During } \\
\text { the last twelve months, would you say you had } \\
\text { difficulties to pay your bills at the end of the } \\
\text { month...? Dichotomous variable: } 0=\text { no; } 1= \\
\text { yes }\end{array}$ & 0.40 & 0.49 & 0 & 1 \\
\hline \multicolumn{6}{|l|}{ Level 2 (Country) } \\
\hline West Europe & $\begin{array}{l}\text { Geographical region of country: Dichotomous } \\
\text { variable: } 0=\text { West Europe; } 1=\text { East Europe }\end{array}$ & 0.39 & 0.49 & 0 & 1 \\
\hline GDP Growth & $\begin{array}{l}\text { Relative difference of GDP from 2008-2011: } \\
\text { Continuous variable }\end{array}$ & 0.004 & 6.82 & -19.35 & 18.18 \\
\hline Social Expenditure & $\begin{array}{l}\text { Total social expenditure, } \% \text { of GDP (public } \\
\text { /mandatory private): Continuous variable }\end{array}$ & 22.88 & 4.73 & 15.1 & 30.84 \\
\hline Unemployment & $\begin{array}{l}\text { Relative difference of unemployment rate from } \\
\text { 2008-2011: Continuous variable }\end{array}$ & 3.77 & 3.26 & -1.6 & 10.1 \\
\hline
\end{tabular}

Sources: Eurobarometer 2011 (individual level), Comparative Political Data Set 2014 (country level) 
Table A2: Determinants of Volunteering in 27 EU-Countries (robust analyses according to influential cases)

\begin{tabular}{|c|c|c|c|c|}
\hline & $\begin{array}{l}\text { Individual } \\
\text { Model } \\
\text { (1) }\end{array}$ & $\begin{array}{l}\text { Country } \\
\text { Model } \\
\text { (2) }\end{array}$ & $\begin{array}{l}\text { Hardship Interaction } \\
\text { Model } \\
\text { (3) }\end{array}$ & $\begin{array}{c}\text { Class Interaction } \\
\text { Model } \\
(4)\end{array}$ \\
\hline Male & $\begin{array}{l}0.071^{* *} \\
(0.032)\end{array}$ & $\begin{array}{l}0.071^{* *} \\
(0.032)\end{array}$ & $\begin{array}{l}0.072^{* *} \\
(0.032)\end{array}$ & $\begin{array}{l}0.069^{* *} \\
(0.032)\end{array}$ \\
\hline Age & $\begin{array}{l}0.002 \\
(0.001)\end{array}$ & $\begin{array}{l}0.002^{*} \\
(0.001)\end{array}$ & $\begin{array}{l}0.002 * \\
(0.001)\end{array}$ & $\begin{array}{l}0.002^{*} \\
(0.001)\end{array}$ \\
\hline Education & $\begin{array}{l}0.079^{* * *} \\
(0.005)\end{array}$ & $\begin{array}{l}0.077^{* * *} \\
(0.005)\end{array}$ & $\begin{array}{l}0.071^{* * *} \\
(0.005)\end{array}$ & $\begin{array}{l}0.077^{* * *} \\
(0.011)\end{array}$ \\
\hline Rural & $\begin{array}{l}0.251^{* * *} \\
(0.037)\end{array}$ & $\begin{array}{l}0.255^{* * *} \\
(0.038)\end{array}$ & $\begin{array}{l}0.255^{* * *} \\
(0.038)\end{array}$ & $\begin{array}{l}0.255^{* * *} \\
(0.038)\end{array}$ \\
\hline Married & $\begin{array}{l}0.140^{* * *} \\
(0.036)\end{array}$ & $\begin{array}{l}0.130^{* * *} \\
(0.037)\end{array}$ & $\begin{array}{l}0.131^{* * *} \\
(0.037)\end{array}$ & $0.130^{* * *}$ \\
\hline Household Size & $\begin{array}{l}0.048^{* * *} \\
(0.014)\end{array}$ & $\begin{array}{l}0.051^{* * *} \\
(0.015)\end{array}$ & $\begin{array}{l}0.051^{* * *} \\
(0.015)\end{array}$ & $\begin{array}{l}0.051^{* * *} \\
(0.015)\end{array}$ \\
\hline White Collar & $\begin{array}{l}-0.157^{* * *} \\
(0.050)\end{array}$ & $\begin{array}{l}-0.154^{* * *} \\
(0.051)\end{array}$ & $\begin{array}{l}-0.154^{* * *} \\
(0.051)\end{array}$ & $\begin{array}{l}-0.142 \\
(0.242)\end{array}$ \\
\hline Blue Collar & $-0.175^{* * *}$ & $-0.197^{* * *}$ & $-0.197^{* * *}$ & 0.046 \\
\hline Unemployed & $\begin{array}{l}(0.058) \\
-0.244^{* * *} \\
(0.064)\end{array}$ & $\begin{array}{l}(0.059) \\
-0.240^{* * *} \\
(0.065)\end{array}$ & $\begin{array}{l}(0.059) \\
-0.236^{* * *} \\
(0.065)\end{array}$ & $\begin{array}{l}(0.299) \\
-0.644^{* *} \\
(0.311)\end{array}$ \\
\hline Economic Hardship & $\begin{array}{l}-0.076^{* *} \\
(0.036)\end{array}$ & $\begin{array}{l}-0.076^{* *} \\
(0.037)\end{array}$ & $\begin{array}{l}-0.427^{* *} \\
(0.175)\end{array}$ & $\begin{array}{l}-0.076^{* *} \\
(0.037)\end{array}$ \\
\hline $\begin{array}{l}\text { Economic Hardship } \times \\
\text { Education }\end{array}$ & & & $\begin{array}{l}0.019^{* *} \\
(0.009)\end{array}$ & \\
\hline White Collar $\times$ Education & & & & $\begin{array}{l}-0.001 \\
(0.012)\end{array}$ \\
\hline Blue Collar $\times$ Education & & & & $\begin{array}{l}-0.013 \\
(0.015)\end{array}$ \\
\hline Unemployed $\times$ Education & & & & $\begin{array}{l}0.023 \\
(0.016)\end{array}$ \\
\hline West Europe & & $\begin{array}{l}0.141 \\
(0.328)\end{array}$ & $\begin{array}{l}0.145 \\
(0.327)\end{array}$ & $\begin{array}{l}0.149 \\
(0.327)\end{array}$ \\
\hline GDP Growth & & $\begin{array}{l}-0.021 \\
(0.019)\end{array}$ & $\begin{array}{l}-0.021 \\
(0.019)\end{array}$ & $\begin{array}{l}-0.021 \\
(0.019)\end{array}$ \\
\hline Social Expenditure & & $\begin{array}{l}0.019 \\
(0.032)\end{array}$ & $\begin{array}{l}0.019 \\
(0.032)\end{array}$ & $\begin{array}{l}0.019 \\
(0.032)\end{array}$ \\
\hline Unemployment & & $\begin{array}{l}-0.048 \\
(0.039)\end{array}$ & $\begin{array}{l}-0.048 \\
(0.039)\end{array}$ & $\begin{array}{l}-0.048 \\
(0.039)\end{array}$ \\
\hline Influential Case & & $\begin{array}{l}0.377 \\
(0.387)\end{array}$ & $\begin{array}{l}0.379 \\
(0.386)\end{array}$ & $\begin{array}{l}(0.376) \\
(0.386)\end{array}$ \\
\hline Constant & $\begin{array}{l}0.329^{* * *} \\
(0.089)\end{array}$ & $\begin{array}{l}0.244^{* * *} \\
(0.069)\end{array}$ & $\begin{array}{l}0.243^{* * *} \\
(0.069)\end{array}$ & $\begin{array}{l}0.242^{* * *} \\
(0.069)\end{array}$ \\
\hline $\mathrm{N}$ & 22,958 & 22,185 & 22,185 & 22,185 \\
\hline Log. Likelihood & $-16,091.15$ & $-15,475.89$ & $-15,473.79$ & $-15,473.49$ \\
\hline Wald chi2 & 472.87 & 449.01 & 451.77 & 452.50 \\
\hline $\mathrm{p}>\mathrm{chi} 2$ & 0.000 & 0.000 & 0.000 & 0.000 \\
\hline AIC & 32208.30 & 30987.79 & 30985.58 & 30988.97 \\
\hline $\mathrm{BIC}$ & 32312.84 & 31131.92 & 31137.71 & 31157.12 \\
\hline
\end{tabular}

Note: Results are from a multilevel mixed-effects ordered logistic regression. Regression coefficients shown with robust standard errors in parentheses. ${ }^{*} \mathrm{p}<0.1,{ }^{* *} \mathrm{p}<0.05$, *** $\mathrm{p}<0.01$. Reference category for white collar, blue collar, and unemployed: Self-employed. 


\section{References}

Andrews, R. (2012). Social capital and public service performance: A review of the evidence. Public Policy and Administration, 27(1), 49-67.

Andrews, R., Jilke, S., \& Van de Walle, S. (2014). Economic strain and social cohesion in Europe: Does institutional trust matter? European Journal of Political Research, 53 (3), 559-579.

Arampatzi, A. (2017). The spatiality of counter-austerity politics in Athens, Greece: Emergent 'urban solidarity spaces'. Urban Studies, 54 (9), 2155-2171.

Armingeon, K., Isler, C., Knöpfel, L., Weisstanner, D., \& Engler, S. (2014). Comparative political data set 1960-2014. Institute of Political Science, University of Bern.

Bakke, E. W. (1933). The unemployed man: A social study. Nisbet.

Belsley, D. A., Kuh, E., \& Welsch, R. E. (2005). Regression diagnostics: Identifying influential data and sources of collinearity. John Wiley \& Sons.

Benenson, J., \& Stagg, A. (2016). An asset-based approach to volunteering: Exploring benefits for low-income volunteers. Nonprofit and Voluntary Sector Quarterly, 45 (1), 131 149.

Berinsky, A. J. (2002). Silent voices: Social welfare policy opinions and political equality in America. American Journal of Political Science, 46 (2), 276-287.

Bjørnskov, C., \& Sønderskov, K. M. (2013). Is social capital a good concept? Social Indicators Research, 114 (3), 1225-1242.

Blekesaune, M. (2013) Economic strain and public support for redistribution: A comparative analysis of 28 European countries. Journal of European Public Policy, 42 (1), $57-72$.

Brady, H. E., Verba, S., \& Schlozman, K. L. (1995). Beyond SES: A resource model of political participation. American Political Science Review, 89 (2), 271-294.

Carpenter, J., \& Myers, C. K. (2010). Why volunteer? Evidence on the role of altruism, image, and incentives. Journal of Public Economics, 94 (11), 911-920.

Coleman, J. S. (1988). Social capital in the creation of human capital. American Journal of Sociology, $94,95-120$.

Curtis, J. E., Baer, D. E., \& Grabb, E. G. (2001). Nations of joiners: Explaining voluntary association membership in democratic societies. American Sociological Review, 66 (6), $783-805$.

Curtis, J. E., Grabb, E. G., \& Baer, D. E. (1992). Voluntary association membership in fifteen countries: A comparative analysis. American Sociological Review, 57 (2), 139-152. 
Eagly, A. H. (2009). The his and hers of prosocial behavior: An examination of the social psychology of gender. American Psychologist, 64 (8), 644-658.

Engbers, T. A., Thompson, M. F., \& Slaper, T. F. (2017). Theory and measurement in social capital research. Social Indicators Research, 132 (2), 537-558.

European Commission. (2014). Eurobarometer 75.2. TNS Opinion \& Social.

European Parliament. (2011). European Parliament Special Eurobarometer 75.2. Voluntary work (27 June 2011). Directorate-General for Communication.

Flanagan, C., \& Levine, P. (2010). Civic engagement and the transition to adulthood. The Future of Children, 20 (1), 159-179.

Foa, R. S., \& Ekiert, G. (2017). The weakness of postcommunist civil society reassessed. European Journal of Political Research, 56 (2), 419-439.

Frankenberg, E., Duncan, T., \& Beegle, K. (1999). The real costs of Indonesian's economic crisis: Preliminary findings from the Indonesian family life surveys. Labour and Population Program. Working Paper Series, 99-04.

Freitag, M. (2003). Social capital in (dis)similar democracies: The development of generalized trust in Japan and Switzerland. Comparative Political Studies, 36 (8), 936966.

Freitag, M. (2006). Bowling the state back in: Political institutions and the creation of social capital. European Journal of Political Research, 45 (1), 123-152.

Fukuyama, F. (2001). Social capital, civil society and development. Third World Quarterly, $22(1), 7-20$.

Gesthuizen, M., Van der Meer, T., \& Scheepers, P. (2008). Education and dimensions of social capital: Do educational effects differ due to educational expansion and social security expenditure? European Sociological Review, 24 (5), 617-632.

Glaeser, E. L., Laibson, D., \& Sacerdote, B. (2002). An economic approach to social capital. The Economic Journal, 112 (483), F437-F458.

Growiec, K., Vilhelmsdóttir, S., \& Cairns, D. (2012). Social capital and financial crisis: The case of Iceland. CISE e-Working Papers, 138, 1-19.

Hackl, F., Halla, M., \& Pruckner, G. J. (2007). Volunteering and income-the fallacy of the good Samaritan? Kyklos, 60 (1), 77-104.

Handy, F., \& Greenspan, I. (2009). Immigrant volunteering: A stepping stone to integration? Nonprofit and Voluntary Sector Quarterly, 38 (6), 956-982.

Hank, K. (2011). Societal determinants of productive aging: A multilevel analysis across 11 European countries. European Sociological Review, 27 (4), 526-541.

Huppert, F. A., Marks, N., Clark, A., Siegrist, J., Stutzer, A., Vittersø, J., \& Wahrendorf, M. (2009). Measuring well-being across Europe: Description of the ESS well-being module and preliminary findings. Social Indicators Research, 91 (3), 301-315. 
Jahoda, M., Lazarsfeld, P. E., \& Zeisel, H. (2002). Marienthal: The sociography of an unemployed community. Transaction Publishers.

Jones, K. S. (2006). Giving and volunteering as distinct forms of civic engagement: The role of community integration and personal resources in formal helping. Nonprofit and Voluntary Sector Quarterly, 35 (2), 249-266.

Kang, C., Handy, F., Hustinx, L., Cnaan, R., Brudney, J. L., Haski-Leventhal, D., Holmes, K., Meijs, L., Pessi, A. B., Ranade, B., Smith, K., Yamauchi, N., \& Zrinscak, S. (2011). What gives? Cross-national differences in students' giving behavior. The Social Science Journal, 48 (2), 283-294.

Kern, A., Marien, S., \& Hooghe, M. (2015). Economic crisis and levels of political participation in Europe (2002-2010): The role of resources and grievances. West European Politics, 38 (3), 465-490.

Kim, J., Kang, J.-h., Lee, M.-A., \& Lee, Y. (2007). Volunteering among older people in Korea. The Journals of Gerontology Series B: Psychological Sciences and Social Sciences, 62(1), 69-73.

Knack, S. (2002). Social capital and the quality of government: Evidence from the states. American Journal of Political Science, 46 (4), 772-785.

Knack, S., \& Keefer, P. (1997). Does social capital have an economic payoff? A crosscountry investigation. The Quarterly Journal of Economics, 112 (4), 1251-1288.

Koos, S. (2011). The institutional embeddedness of social responsibility: A multilevel analysis of smaller firms' civic engagement in Western Europe. Socio-Economic Review, $10(1), 135-162$.

Levi, M. (1996). Social and unsocial capital: A review essay of Robert Putnam's making democracy work. Politics \& Society, 24 (1), 45-55.

Lim, C., \& Laurence, J. (2015). Doing good when times are bad: volunteering behaviour in economic hard times. British Journal of Sociology, 66 (2), 319-344.

Lim, C., \& Sander, T. (2013). Does misery love company? Civic engagement in economic hard times. Social Science Research, 42 (1), 14-30.

Lin, N. (2002). Social capital: A theory of social structure and action. Cambridge University Press.

Lipset, S. M. (1960). The social bases of politics. The Johns Hopkins University Press.

Mahoney, C., \& Beckstrand, M. J. (2011). Following the money: European Union funding of civil society organizations. JCMS: Journal of Common Market Studies, 49 (6), 1339-1361.

Manatschal, A., \& Freitag, M. (2014). Reciprocity and volunteering. Rationality and Society, $26(2), 208-235$. 
McBride, A. M., Gonzales, E., Morrow-Howell, N., \& McCrary, S. (2011). Stipends in volunteer civic service: Inclusion, retention, and volunteer benefits. Public Administration Review, 71 (6), 850-858.

Van der Meer, T., Te Grotenhuis, M., \& Pelzer, B. (2010). Influential cases in multilevel modeling: A methodological comment. American Sociological Review, 75(1), 173-178.

Muñoz, J., Anduiza, E., \& Rico, G. (2014). Empowering cuts? Austerity policies and political involvement in Spain. In S. Kumlin \& I. Stadelmann-Steffen (Eds.), How welfare states shape the democratic public: Policy feedback, participation, voting and attitudes (pp. 19-40). Edward Elgar.

Musick, M. A., \& Wilson, J. (2007). Volunteers: A social profile. Indiana University Press.

Newton, K. (1999). Social capital and democracy in modern Europe. In J. W. van Deth, M. Maraffi, K. Newton, \& P. E. Whiteley (Eds.), Social capital and European democracy (pp. 3-22). Routledge.

Norris, P. (2001). Making democracies work: Social capital and civic engagement in 47 societies. Paper presented at the European Science Foundation EURESCO Conference on Social Capital: Interdisciplinary Perspectives at the University of Exeter, 15-20 September.

Olson, M. (1965). Logic of collective action: Public goods and the theory of groups. Harvard University Press.

Paxton, P. (2002). Social Capital and Democracy: An Interdependent Relationship. American Sociological Review 67: 254-277.

Petrzelka, P., \& Mannon, S. E. (2006). Keepin' this little town going: Gender and volunteerism in rural America. Gender \& Society, 20 (2), 236-258.

Pho, Y. H. (2008). The value of volunteer labor and the factors influencing participation: Evidence for the United States from 2002 through 2005. Review of Income and Wealth, 54 (2), 220-236.

Plagnol, A. C., \& Huppert, F. A. (2010). Happy to help? Exploring the factors associated with variations in rates of volunteering across Europe. Social Indicators Research, 97 (2), 157-176.

Portes, A. (1998). Social capital: Its origins and applications in modern sociology. Annual Review of Sociology, 24 (1), 1-24.

Powell, F., \& Guerin, D. (1997). Civil society and social policy: Voluntarism in Ireland. A. \& A. Farmar.

Putnam, R. D. (1993a). The prosperous community. The American Prospect, 4 (13), $35-$ 42.

Putnam, R. D. (1993b). Making democracy work: Civic traditions in modern Italy. Princeton University Press. 
Putnam, R. D. (1995). Bowling alone: America's declining social capital. Journal of Democracy, 6 (1), 65-78.

Putnam, R. D. (2000). Bowling alone: The collapse and revival of American community. Simon \& Schuster.

Putnam, R. (2001). Social capital: Measurement and consequences. Canadian Journal of Policy Research, 2 (1), 41-51.

Putnam, R. D., \& Goss, K. A. (2002). Introduction. In R. D. Putnam (Ed.), Democracies in flux: The evolution of social capital in contemporary society (pp. 13-20). Oxford University Press.

Rotolo, T. (1999). Trends in voluntary association participation. Nonprofit and Voluntary Sector Quarterly, 28 (2), 199-212.

Rothstein, B., \& Stolle, D. (2003). Introduction: social capital in Scandinavia. Scandinavian Political Studies, 26 (1), 1-26.

Ruiter, S., \& De Graaf, N. D. (2008). Socio-economic payoffs of voluntary association involvement: A Dutch life course study. European Sociological Review, 25 (4), 425-442.

Ruiter, S., \& De Graaf, N. D. (2006). National context, religiosity, and volunteering: Results from 53 countries. American Sociological Review, 71 (2), 191-210.

Schofer, E., \& Fourcade-Gourinchas, M. (2001). The structural contexts of civic engagement: Voluntary association membership in comparative perspective. American Sociological Review, 66 (6), 806-828.

Shye, S. (2010). The motivation to volunteer: A systemic quality of life theory. Social Indicators Research, 98 (2), 183-200.

Singer, M. M. (2011). Who says "it's the economy"? Cross-national and cross-individual variation in the salience of economic performance. Comparative Political Studies, 44 (3), $284-312$.

Sotiropoulos, D. (2014). Civil society in Greece in the wake of the economic crisis. Report for Konrad Adenauer Stiftung \& ELIAMEP.

Stadelmann-Steffen, I. (2011). Social volunteering in welfare states: Where crowding out should occur. Political Studies, 59 (1), 135-155.

Steenbergen, M. R., \& Jones, B. S. (2002). Modeling multilevel data structures. American Journal of Political Science, 46 (1), 218-237.

Stolle, D., \& Rochon, T. R. (1998). Are all associations alike? Member diversity, associational type, and the creation of social capital. American Behavioral Scientist, 42 (1), 47-65.

Taniguchi, H. (2012). The determinants of formal and informal volunteering: Evidence from the American Time Use Survey. Voluntas: International Journal of Voluntary and Nonprofit Organizations, 23 (4), 920-939. 
Tang, F., Morrow-Howell, N., \& Choi, E. (2010). Why do older adult volunteers stop volunteering? Ageing \& Society, 30 (5), 859-878.

The Washington Post (2009). In recession, some see burst of "neigbboring" (4 May 2009). URL: http://www.washingtonpost .com/wp-dyn/content/article/2009/05/03/ AR2009050302330.html (last accessed on May 11, 2018).

The Guardian (2008). Recession sends volunteer numbers soaring (21 December 2008). URL: http://www.theguardian.com/travel/2008/ dec/21/volunteer-voluntarywork-overseas (last accessed on May 11, 2018).

The Telegraph (2009). Everybody needs good neighbours (21 April 2009). URL: http://www.telegraph.co.uk/news/5195355/Everybody-needs-goodneighbours.html (last accessed on May 11, 2018).

Van der Meer, T., Te Grotenhuis, M., \& Pelzer, B. (2010). Influential cases in multilevel modeling: A methodological comment. American Sociological Review, 75 (1), 173-178.

Van Deth, J. W., Gabriel, O. W., \& Roßteutscher, S. (2002). Sozialkapital und Demokratie: Zivilgesellschaftliche Ressourcen im Vergleich. Wien: WUV-UniversitätsVerlag.

Verba, S., Schlozman, K. L., \& Brady, H. E. (1995). Voice and equality: Civic voluntarism in American politics. Harvard University Press.

Voicu, B., \& Voicu, M. (2009). Volunteers and volunteering in Central and Eastern europe. Sociológia, 41 (6), 539-563.

Warren, M. E. (2001). Democracy and association. Princeton University Press.

Welzel, C. (2010). How selfish are self-expression values? A civicness test. Journal of Cross- Cultural Psychology, 41 (2), 152-174.

Welzel, C., \& Inglehart, R. (2010). Agency, values, and well-being: A human development model. Social Indicators Research, 97 (1), 43-63.

Williams, J. (2011). Geographic variations in health care utilization: Effects of social capital and self-interest, and implications for US medicare policy. Socio-Economic Review, 10 (2), 317-342.

Wilson, J. (2000). Volunteering. Annual Review of Sociology, 26 (1), 215-240.

Wilson, J. (2012). Volunteerism research: A review essay. Nonprofit and Voluntary Sector Quarterly, 41 (2), 176-212.

Wilson, J., \& Musick, M. (1997). Who cares? Toward an integrated theory of volunteer work. American Sociological Review, 62 (5), 694-713.

Wilson, J., \& Musick, M. (1998). The contribution of social resources to volunteering. Social Science Quarterly,79 (4), 799-814. 
Wosiek, M. (2016). Social capital under conditions of economic crisis - the example of Southern European countries. Ekonomia i Prawo. Ecomomics and Law, 15 (3), $401-$ 414.

Zambeta, E., \& Kolofousi, A. (2014). Education and social solidarity in times of crisis: The case of voluntary shadow education in Greece. Education Inquiry, 5 (1), 69-88.

Zmerli, S. (2003). Applying the concepts of bonding and bridging social capital to empirical research. European Political Science, 2 (3), 68-75. 